\title{
Spectrophotometric Method for the Determination of Atmospheric Cr Pollution as a Factor to Accelerated Corrosion
}

\author{
Dereje Homa, Ermias Haile, and Alemayehu P. Washe \\ Department of Chemistry, Hawassa University, P.O. Box 05, Hawassa, Ethiopia \\ Correspondence should be addressed to Alemayehu P. Washe; alemayehup@yahoo.com
}

Received 24 December 2016; Accepted 16 March 2017; Published 2 April 2017

Academic Editor: Jaroon Jakmunee

Copyright (c) 2017 Dereje Homa et al. This is an open access article distributed under the Creative Commons Attribution License, which permits unrestricted use, distribution, and reproduction in any medium, provided the original work is properly cited.

\begin{abstract}
The effect of $\mathrm{Cr}(\mathrm{VI})$ pollution on the corrosion rate of corrugated iron roof samples collected from tanning industry areas was investigated through simulated laboratory exposure and spectrophotometric detection of $\mathrm{Cr}$ (III) deposit as a product of the reaction. The total level of $\mathrm{Cr}$ detected in the samples ranged from $113.892 \pm 0.17 \mathrm{ppm}$ to $53.05 \pm 0.243 \mathrm{ppm}$ and showed increasing trend as sampling sites get closer to the tannery and in the direction of tannery effluent stream. The laboratory exposure of a newly manufactured material to a simulated condition showed a relatively faster corrosion rate in the presence of $\mathrm{Cr}$ (VI) with concomitant deposition of $\mathrm{Cr}(\mathrm{III})$ under $\mathrm{pH}$ control. A significant $(P=0.05)$ increase in the corrosion rate was also recorded when exposing scratched or stress cracked samples. A coupled redox process where $\mathrm{Cr}(\mathrm{VI})$ is reduced to a stable, immobile, and insoluble $\mathrm{Cr}(\mathrm{III})$ accompanying corrosion of the iron is proposed as a possible mechanism leading to the elevated deposition of the latter on the materials. In conclusion, the increased deposits of $\mathrm{Cr}$ detected in the corrugated iron roof samples collected from tanning industry zones suggested possible atmospheric Cr pollution as a factor to the accelerated corrosion of the materials.
\end{abstract}

\section{Introduction}

Accelerated corrosion of corrugated iron roof (galvanizedsteel) is a subject of global concern because of its importance to the service life of the material and its aesthetic appearance $[1,2]$. Atmospheric corrosion is the result of a redox reaction between the metal component of the material and its atmospheric environment that occurs in the presence of a conducting thin aqueous adlayer [3]. The common incorporation of pollutant species into this adlayer usually enhances the degradation process. Although steel structures are employed in atmospheric environments with some means of surface protection, considerable researches have demonstrated the effects of both steel alloy composition and atmospheric environments on its corrosion behavior [1]. For instance, the ability of zinc to galvanically protect iron is relatively effective in neutral environment but very sensitive to any change of atmospheric acidity [2]. Air pollutants such as sulfur dioxide, hydrogen sulphide, oxides of nitrogen, and chlorides and weathering factors such as temperature, moisture, rainfall, solar radiation, and wind velocity have been recognized as conventional atmospheric parameters that may contribute to the corrosion [1-3]. Industrial sites particularly those in most tropical locations are the most corrosive sites due to the polluting chemicals (such as $\mathrm{H}_{2} \mathrm{~S}$ and $\mathrm{SO}_{2}$-precursors of acid rain), solid particles in the atmosphere including soot, the time of wetness (humidity), and the high temperature experienced $[1,2]$. The synergistic interaction of the atmospheric pollution variables and coupled processes can also play considerable role in the corrosion phenomena. For instance, the presence of metallic pollutants such as $\mathrm{Cr}$ that can galvanically couple with the iron of the roofing material through the adlayer can accelerate the degradation process [4-7]. The major sources of $\mathrm{Cr}$ in the atmosphere are industries including leather tanning industries, textile (printing, dyeing), chromium plating, steel production, and refractories $[8,9]$. Among these, the leather tanning industry is the major source of chromium in the environment due to the disposal of chromium-contaminated sludge [9-11]. Studies have already indicated the above regulation limit contamination of soil, water, and vegetables in villages adjacent to tanneries by Cr [12-14]. Although Cr(III) is the most expected form in 
the tannery effluents, the incidence of the hexavalent form can occur due to redox transformations occurring in the sludge [15-18]. Chromium may also present in the atmosphere in the form of particulates and aerosol droplets [1921]. Chromium from sources releasing the element in lager particles (particle diameter varies $0.2-50 \mu \mathrm{m}$ ) is deposited locally and can migrate through individual environmental media. Transport within the terrestrial and water systems is greatly affected by chemical speciation; chemical forms of chromium and their affinity to chemical and photochemical redox transformations; precipitation/dissolution and adsorption/desorption process, for example, occurring in individual compartments of the biogeochemical cycle of chromium [20]. Redox conversion of $\mathrm{Cr}^{3+}$ to $\mathrm{Cr}^{6+}$ can increase $\mathrm{Cr}^{6+}$ dislocation from the soil into the water systems and the atmosphere [20,21]. Previous researchers have demonstrated that $\mathrm{Cr}(\mathrm{VI})$ is stable in oxidizing environment with $\mathrm{pH}$ above 6.0 but tends to reduce to more thermodynamically stable and insoluble $\mathrm{Cr}(\mathrm{OH})_{3}$ under conditions of $\mathrm{pH} 3$ to $6[22$, 23]. The hexavalent chromium can also be reduced to the trivalent chromium compound through a coupled reaction that causes iron corrosion [4-6]. Reduction of $\mathrm{Cr}(\mathrm{VI})$ to $\mathrm{Cr}$ (III) by reaction with zerovalent iron $\left(\mathrm{Fe}^{0}\right)$ and subsequent precipitation of $\mathrm{Cr}$ (III) oxyhydroxides can occur through the reaction sequence [4]:

$$
\begin{aligned}
& \mathrm{CrO}_{4(\mathrm{aq})}^{2-}+\mathrm{Fe}_{(\mathrm{s})}^{0}+8 \mathrm{H}_{(\mathrm{aq})}^{+} \longrightarrow \mathrm{Fe}_{(\mathrm{aq})}^{3+}+\mathrm{Cr}_{(\mathrm{aq})}^{3+}+4 \mathrm{H}_{2} \mathrm{O}_{(\mathrm{l})} \\
& (1-x) \mathrm{Fe}_{(\mathrm{aq})}^{3+}+(x) \mathrm{Cr}_{(\mathrm{aq})}^{3+}+2 \mathrm{H}_{2} \mathrm{O}_{(\mathrm{l})} \\
& \longrightarrow \mathrm{Fe}_{(1-x)} \mathrm{Cr}_{x} \mathrm{OOH}_{(\mathrm{s})}+3 \mathrm{H}_{(\mathrm{aq})}^{+}
\end{aligned}
$$

Such coupled redox reactions are well known from bimetallic corrosion. Because the zerovalent iron and $\mathrm{Cr}(\mathrm{VI})$ have different natural reduction potentials, current will flow from the cathode $\mathrm{Cr}(\mathrm{VI})$ to the anode (iron) metal via the conducting liquid at the metallic junctions under moist conditions, which will increase the corrosion rate on the anode. Acidic moisture from precipitation, fog or dew, or other sources serves as an electrolyte in this type of atmospheric galvanic corrosion. Since there is an excess of oxygen in the atmosphere, the corrosion of iron sheet in atmospheric environment is not limited by the amount of oxygen present and can proceed rapidly when the electrolyte is present. The electrochemical cell configuration thus consists of one metal (more electropositive) as anode and the other as cathode (more electronegative) connected via the junction electrolyte as indicated in Scheme 1 [24].

Since the trivalent chromium compounds are thermodynamically stable, immobile, and sparingly soluble, it is envisaged that the level of $\mathrm{Cr}$ in the roofing material might increase (above the initial level in the alloyed materialsteel) as a result of reduction of $\mathrm{Cr}(\mathrm{VI})$ to $\mathrm{Cr}(\mathrm{III})$ by reaction with $\mathrm{Fe}^{0}$ and subsequent precipitation of $\mathrm{Cr}(\mathrm{III})$. The objective of the current study is, therefore, to determine chromium deposits on roofing iron as both a factor and indicator for accelerated corrosion of the roofing iron sheets by chromium (VI) transformation in adjacent villages of

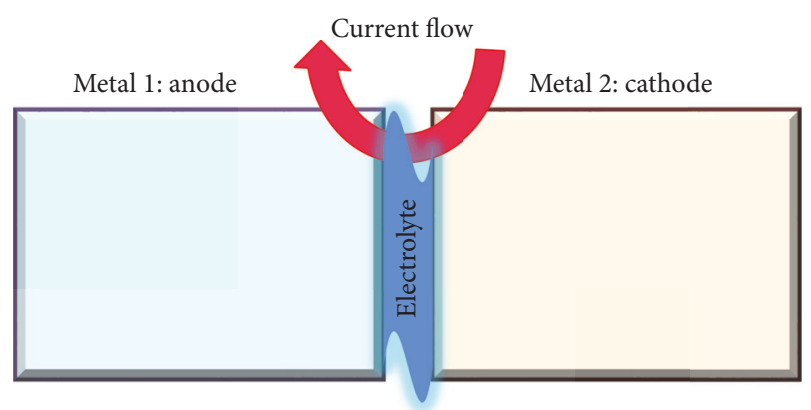

Scheme 1: Electrochemical cell configuration for bimetallic corrosion.

the Akaki-Kaliti industrial zone of Ethiopia. Several analytical techniques including inductively coupled plasma-mass spectrometry (ICP-MS), inductively coupled plasma-atomic emission spectrometry (ICP-AES), electrochemical analysis, spectrophotometry, neutron activation analysis, and atomic absorption spectrophotometry (AAS) are available for the determination and speciation of $\mathrm{Cr}(\mathrm{III})$ and $\mathrm{Cr}(\mathrm{VI})$ either in off-line or in on-line methods $[25,26]$.

In this study off-line procedures are employed in the spectrophotometric determination and speciation of $\mathrm{Cr}$ (III) and $\mathrm{Cr}(\mathrm{VI})$ because of its simplicity. Spectrophotometric determination of $\mathrm{Cr}(\mathrm{VI})$ by complexation with 1,5-diphenylcarbazide was used as a quicker and easier method [27]. Thus AAS was used for the determination of total $\mathrm{Cr}$ and UV-Vis for $\mathrm{Cr}(\mathrm{VI})$. Speciation was carried out based on the difference of results from the two methods. A simulated laboratory exposure of a newly manufactured corrugated iron sample to synthetic corrosive air was also conducted under different conditions to study the transformation of $\mathrm{Cr}(\mathrm{VI})$ to $\mathrm{Cr}(\mathrm{III})$ and the accelerated corrosion of the iron material in the coupled galvanic process. Exposure of a metal to a corrosive atmosphere leads to the formation of corrosion products, which usually remain on the surface leading to mass gain. Laboratory exposure of metals to synthetic environments containing $\mathrm{SO}_{2}$ and/or $\mathrm{NO}_{2}$ with humidified air has been used by different research groups for the investigation of the atmospheric corrosion of metals and proved to be reliable [28-31].

\section{Materials and Methods}

2.1. Description of the Study Area and Study Design. The research was conducted at Akaki-Kaliti industrial zones of Ethiopia which is located to the south of Addis Ababa in the Akaki-Kaliti subcity. The subcity covers an area of 124.7 sq.km with a total population of 194,002, 2015 census. More than 200 industries including the Ethiopian Tannery Share Company (ETSC) have been registered in the subcity. Based on the interview made with households residing in the subcity and appropriate stakeholders including Addis Ababa Environmental Protection Authority, villages adjacent to the Ethiopian Tannery Share Company (ETSC) were selected as the target sites. The ETSC is located $85 \mathrm{~km}$ southeast of Addis Ababa with a grid reference of $8^{\circ} 27.154^{\prime}$ latitude 
and $39^{\circ} 03.894^{\prime}$ longitudes. This area is characterized by a semiarid climate having an altitude of $1630 \mathrm{~m}$, an average annual rainfall of $800 \mathrm{~mm}$, and minimum and maximum temperature of $17.5^{\circ} \mathrm{C}$ and $26^{\circ} \mathrm{C}$, respectively. Samples of roofing iron were then systematically collected within a kilometer radius of effluent discharge point.

2.2. Samples Collection and Preparation. Three different groups of the roofing iron materials were collected. The first group consisted of samples collected from areas very close to tanning industry zones where a high level of $\mathrm{Cr}$ emissions was reported by previous researchers [12-14]. These samples were collected from two directions: along the direction of the tannery effluent discharge line (east corrugated) and opposite to the direction of the tannery effluent discharge line (west corrugated). Four sampling sites at $100 \mathrm{~m}$ intervals were considered in each case giving a total of eight samples. Only samples with the same years of service that appeared corrosively damaged were systematically selected. The second group of samples referred to as control groups were collected from presumably natural environment in rural areas that are about $200 \mathrm{~km}$ and farther from industrial sites. The third group of samples called a universal control consisted of the newly manufactured corrugated roofing iron purchased from four different shops. All the samples belonged to the same brand and manufacturer. The samples were cut into pieces with plastic nail and packaged in plastic bag containers and transported to the laboratory. The sampling was carried out in March 5 to 9/2016.

2.3. Instrument, Apparatus, and Chemicals. In this work Flame Atomic Absorption Spectrophotometer (Buck Scientific, Model 210VGP AAS, USA) equipped with deuterium background corrector and air-acetylene flame atomizer was used for determination of the total Cr in corrugated iron samples. Spectrophotometer (model UNICAM UV-300, England) was used for determination of $\mathrm{Cr}(\mathrm{VI})$. All the samples were weighed on a digital microbalance with a $0.0002 \mathrm{mg}$ precision. Stock standard solutions (Buck Scientific calibration standards, USA) containing $1000 \mathrm{mg} / \mathrm{L}$ of total $\mathrm{Cr}$ metals were used. Instrumental parameters of the FAAS for determination of total $\mathrm{Cr}$ were adjusted according to the manufacturer recommendation. The correlation coefficient of the calibration curve for the metal was 0.9992 which assured the linearity of instrumental response for analytes. For $\mathrm{Cr}(\mathrm{VI})$ a blank and the standard solutions were analyzed with UVVisible spectrophotometer with $1 \mathrm{~cm}$ quartz cell which was used and the absorbance measurements were performed in the range of $300-800 \mathrm{~nm}$. The absorption maxima were observed at $540 \mathrm{~nm}$ and $r=0.998$. 1,5-Diphenylcarbazide (BDH, India) complex and $\mathrm{K}_{2} \mathrm{Cr}_{2} \mathrm{O}_{7}$ were used for the preparation of standard solutions. Deionized water was used for all solution preparation solutions.

2.4. Sample Digestion and Preparation for FAAS. Digestion of iron samples was performed following the optimized conditions. Briefly, $1.00 \mathrm{~g}$ of the corrugated roofing iron was cut into small pieces, dissolved in $30 \mathrm{ml}$ of $5 \mathrm{M} \mathrm{HCl}$ and $10 \mathrm{ml}$ conc. $\mathrm{HNO}_{3}$, and heated in the solution at $75^{\circ} \mathrm{C}$ for $1 \mathrm{hr}$. Then the solution was filtered into a $100 \mathrm{ml}$ volumetric flask and diluted with distilled water up to the mark. Each of the above iron samples was digested in triplicate.

\subsection{Speciation through Determination of $\mathrm{Cr}(\mathrm{VI})$ by UV-Vis} Spectrophotometer. An analytical grade of $250 \mathrm{mg}$ of 1,5diphenylcarbazide (DPC), a common complexing agent of chromium (VI) for spectrophotometric analysis, was taken and dissolved with acetone and diluted to $100 \mathrm{ml}$ with distilled water. Then a freshly prepared $1 \mathrm{ml}$ of DPC was added to each sample and aged until a red violet colour was developed. Analytical grade $0.5 \mathrm{~g}$ of $\mathrm{K}_{2} \mathrm{Cr}_{2} \mathrm{O}_{7}$ was taken and dissolved with deionized water and diluted to $500 \mathrm{ml}$. Then $10 \mathrm{ml}$ of the standard was taken and further diluted to $100 \mathrm{ml}$. A series of ten standards containing $1,0.5,0.2,0.04$, and $0.01 \mathrm{mg}$ were prepared and acidified with $0.2 \mathrm{~N}$ of $5 \mathrm{ml}$ of sulfuric acid. Then a freshly prepared $1 \mathrm{ml}$ of DPC was added to each standard and a pink colour was immediately developed. Then sample analysis was performed on the clear solutions obtained from the digestion procedure after filtration through Whatman number 45 for analysis by the 1,5-diphenylcarbazide method at $540 \mathrm{~nm}$.

2.6. Laboratory Exposures. To study the impact of $\mathrm{Cr}(\mathrm{VI})$ pollution on atmospheric corrosion of corrugated iron roof, an atmosphere with controlled gaseous corrosion simulators was used. A home built humidity chamber was employed where the synthetic corrosive air generated in a separate reactor and humidified air from opposite source was mixed in a column where the iron sample was held [32]. The corrugated iron sample was previously exposed to different conditions prior to exposure to the synthetic air. The exposure to acidic condition was carried out by submerging the sample in $\mathrm{H}_{2} \mathrm{SO}_{4}$ solutions of different $\mathrm{pH}(3,5,7$, and 9) in presence and absence of $\mathrm{Cr}(\mathrm{VI})$ for 30 minutes to form a surface layer containing the required chemicals and then dried at $55-60^{\circ} \mathrm{C}$ and weighed before exposure to the corrosive air. Then the control samples (submerged in MQ water at $\mathrm{pH}=7$ ) and test samples of different wet surfaces were taken out, dried, weighed, and placed in the reaction chamber where they were further exposed to synthetic air. The synthetic air is composed of the humidified air and the corrosive air generated in separate sources and allowed to get mixed in the exposure chamber, where the iron sample was held. The container of MQ water was submerged in a thermostatic bath to maintain the temperature at $25 \pm 0.5^{\circ} \mathrm{C}$. A schematic description of the experimental set-up for exposure of corrugated iron roof to simulated atmospheric condition is shown in Scheme 2. The exposure chamber was constructed using a simple distillation flask with double side arms, an ambient air circulator, and septum as a covering lid. The ambient air enters from above through a ball valve and gets mixed with lateral flows of humidified and synthetic corrosive air near the surface of the iron sample. The synthetic corrosive air containing $\mathrm{SO}_{2}$ was produced by roasting (heating in the presence of oxygen) $\mathrm{FeS}_{2}$. Reaction rate was controlled by monitoring the temperature and replenishing the reactant as deemed necessary. The $\mathrm{SO}_{2}$ generated was pumped into the reaction chamber. The humidified air was generated by passing dry air through 


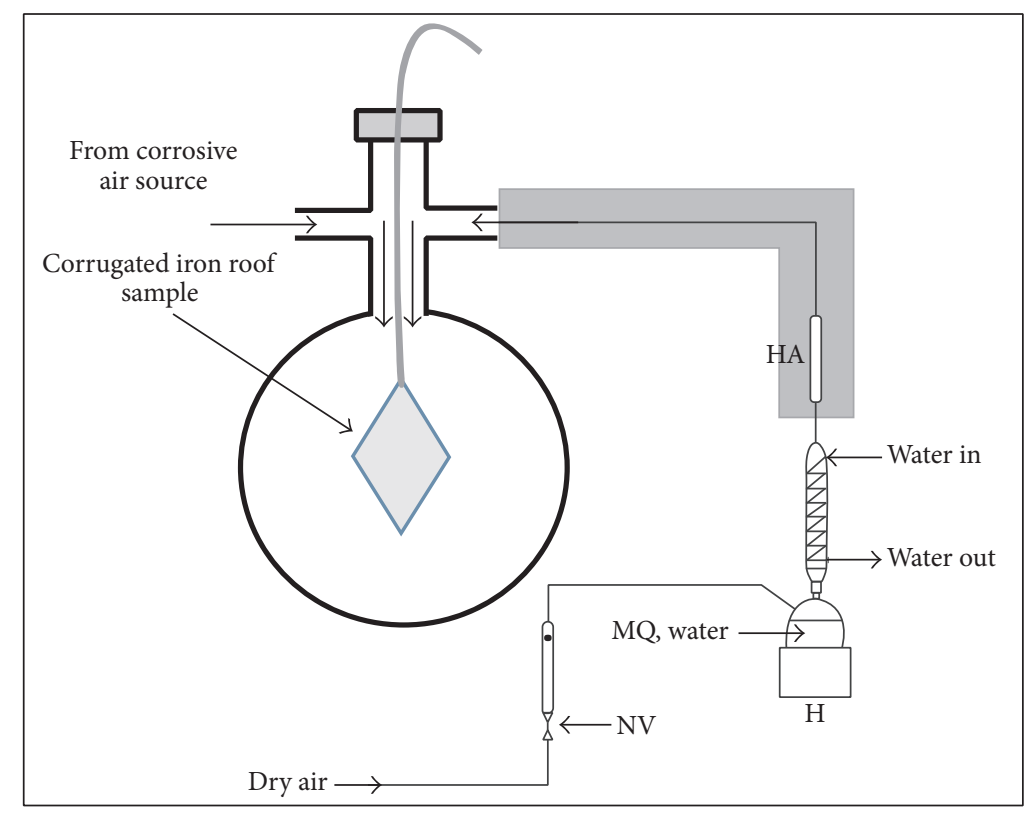

SCHEMe 2: Schematic experimental set-up to exposure of corrugated iron roof to simulated atmospheric condition $(\mathrm{HA}=$ humid air; $\mathrm{NV}=$ valve).

a heated MQ water cooled by a circulation tap water. The dry air had a flux of $1.31 \mathrm{~min}^{-1}$, corresponding to a velocity of $3.5 \mathrm{~cm} \cdot \mathrm{s}^{-1}$ over the sample, which is in the lower range of normal indoor air-flow conditions [33]. The experiments were followed for 60 days and ex situ FAAS measurements and speciation analysis on the iron samples were made after exposure in the chamber. Similar procedure of digestion as described above was used for sample preparation for the FAAS and speciation analysis.

2.7. Method Validation. To verify the accuracy and precision (repeatability) of the method, recovery study was carried out using standard solutions spiked on triplicates of the corrugated iron. The good recovery values obtained confirmed the accurate determination of $\mathrm{Cr}(\mathrm{VI})$ and total chromium by UVVis and FAAS, respectively. At 95\% confidence level, the range of $\%$ recovery was found to be $93.00 \pm 3.09$ to $105 \pm 4.27$ with $t=4.30$ and degree of freedom 2 for $n=3$.

2.8. Statistical Analysis. Statistical significance of the differences in the levels of $\mathrm{Cr}$ detected in duplicate samples of different types or sites (with reference to tannery effluent outlet point) was evaluated using one-way ANOVA at $P=0.05$. All statistical analyses were performed using SAS Version 9.1.

\section{Results and Discussions}

3.1. Determination of Chromium in Corrugated Iron. Chromium is naturally present in corrugated iron roof as component of the steel alloy. But this natural level is expected to increase with Fe coupled atmospheric transformation of the hexavalent $\mathrm{Cr}$ into the trivalent $\mathrm{Cr}$ in areas where industrial activities can lead to atmospheric pollution by $\mathrm{Cr}(\mathrm{VI})$. We determined total $\mathrm{Cr}$ levels as well as the levels of major species $(\mathrm{Cr}(\mathrm{III})$ and $\mathrm{Cr}(\mathrm{VI}))$ from speciation experiments in three different groups of the roofing material. The levels of total $\mathrm{Cr}$ corrected for blank (new material) detected in exposed samples against distance from the tannery are presented in Figure 1. The levels of total $\mathrm{Cr}$ detected in the damaged materials ranged from $113.892 \pm 0.17 \mathrm{ppm}$ to $53.05 \pm 0.243 \mathrm{ppm}$. The levels showed a decreasing trend with distance from the tannery. The mean concentrations of $\mathrm{Cr}$ in new corrugated iron samples purchased from four shops and that of four control samples collected at 100, 200, 300 , and $400 \mathrm{~km}$ distances farther from the tannery were 8.5 \pm 0.045 and $9.66 \pm 0.704 \mathrm{ppm}$, respectively. The maximum levels of $\mathrm{Cr}$ detected in new and control samples were 8.908 and $10.433 \mathrm{ppm}$, respectively, which is still lower than the minimum level detected in exposed and damaged samples. No significant differences $(P=0.05)$ among the levels of $\mathrm{Cr}$ in control samples collected at different distances $(100 \mathrm{~km}$ and above) were detected. Similarly the levels of $\mathrm{Cr}$ in the new corrugated iron materials purchased from four shops did not show significant $(P=0.05)$ differences.

A speciation experiment showed a similar trend in the levels of $\mathrm{Cr}$ (III) and $\mathrm{Cr}(\mathrm{VI})$ but with low levels of the latter as compared to the former. The highest concentration of $\mathrm{Cr}(\mathrm{III})$ and $\mathrm{Cr}(\mathrm{VI})$ was $111.876 \pm 0.17$ and $2.453 \pm 1.54 \mathrm{ppm}$, respectively, in samples collected at industrial sites.

3.2. Directionality of $\mathrm{Cr}$ Pollution against Effluent Stream. Interestingly, the profile of chromium deposits in the corrugated roofing iron samples showed variation with the direction of the effluent discharge. The concentration was highest in samples collected at the direction of effluent discharge 


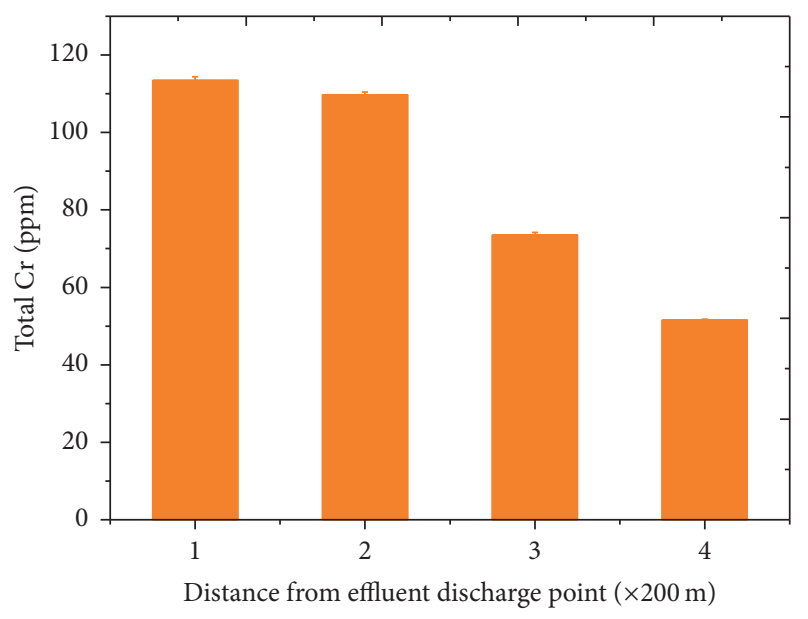

Figure 1: The levels of total Cr(III) corrected for blank (new material) detected in exposed samples against distance from the tannery.

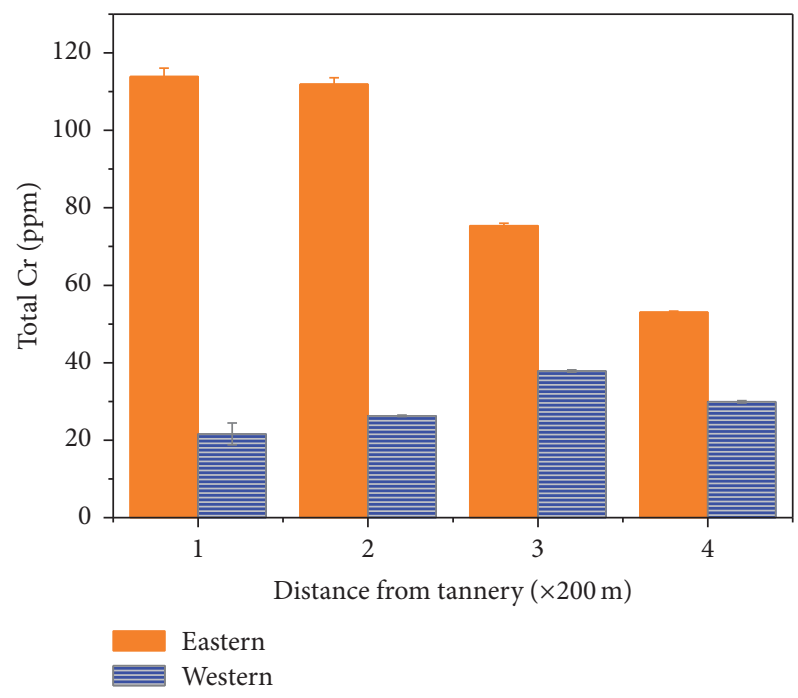

FIgure 2: Directional dependence of Cr deposited on the roofing material.

(eastern direction). The results of directional dependence of $\mathrm{Cr}$ deposited on the roofing material are shown in Figure 2. Both sets of results reinforce the proposal that the $\mathrm{Cr}(\mathrm{VI})$ that might be present in the atmosphere of industrial areas as a result of dislocation or direct emission can transform into the less mobile and insoluble $\mathrm{Cr}$ (III) form to increase the load of the latter.

From Figures 2 and 3 it can be summarized that the level of $\mathrm{Cr}$ deposits increases in the order: new corrugated, control corrugated, west corrugated, and east corrugated. The increased load of $\mathrm{Cr}$ on the iron samples collected at areas in the vicinity of the tanning industry suggests a possible presence of $\mathrm{Cr}(\mathrm{VI})$ in the atmosphere that can undergo a coupled transformation to $\mathrm{Cr}$ (III). The latter can also settle on the iron materials through direct emission. But considering the mobility and solubility behavior of $\mathrm{Cr}$ (III) the former suggestion seems sounder than the latter. The results of

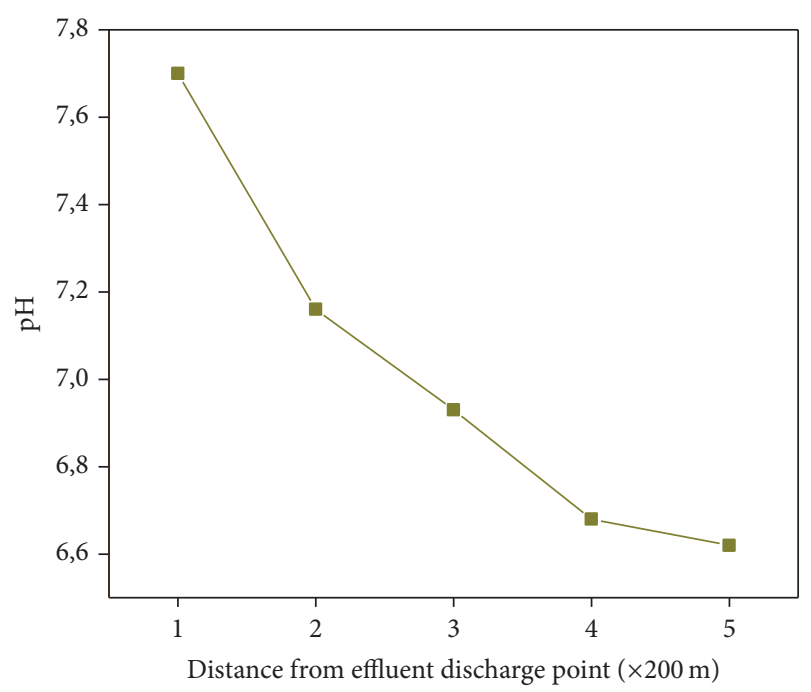

FIGURE 3: The $\mathrm{pH}$ of the corroded corrugated iron materials collected at different distances from the tannery discharge point.

laboratory exposure studies performed to verify the above findings and proposed explanations are presented in the subsequent sections.

3.3. $p H$ Characterization of Degraded Corrugated Iron Samples. $\mathrm{pH}$ is a very important factor in the environmental transformation of chemicals. And also the $\mathrm{pH}$ of industrial atmospheres particularly those of tanning industries is expected to be different from that of other areas due to emissions of acid precursor gases $\left(\mathrm{H}_{2} \mathrm{~S}\right.$ and $\left.\mathrm{SO}_{2}\right)$. The $\mathrm{pH}$ of environmental samples, the corrugated iron roof materials in this case, collected at areas in the vicinity of tanning industries thus needs to be determined as indicator of the corrosivity of the atmosphere. The $\mathrm{pH}$ of the degraded corrugated iron materials collected at different distances from the tannery discharge point is shown in Figure 3. An increasing trend in the $\mathrm{pH}$ of the samples with distance from the tannery can be observed. This finding is consistent with the fact that proximity to anthropogenic activities determines the level of environmental pollution. In other words, the environmental samples get more and more acidic as they get closer and closer to the industries, especially the tanning industry. The increase in $\mathrm{pH}$ with distance might be due to exposure of the water to the atmosphere which can lead to dissolution of $\mathrm{SO}_{2}$ in the atmosphere. The $\mathrm{pH}$ values did not fall below 6 which is consistent with the finding that the dominant form of $\mathrm{Cr}$ in the samples was the basic trivalent form.

3.4. A Simulated Laboratory Exposure Study. In order to study the transformation of $\mathrm{Cr}(\mathrm{VI})$ to $\mathrm{Cr}(\mathrm{III})$ and the accelerated corrosion of the iron material in the coupled galvanic process, a simulated laboratory exposure experiment on a newly manufactured corrugated iron sample was conducted under varied conditions. Following the exposure, mass gain 


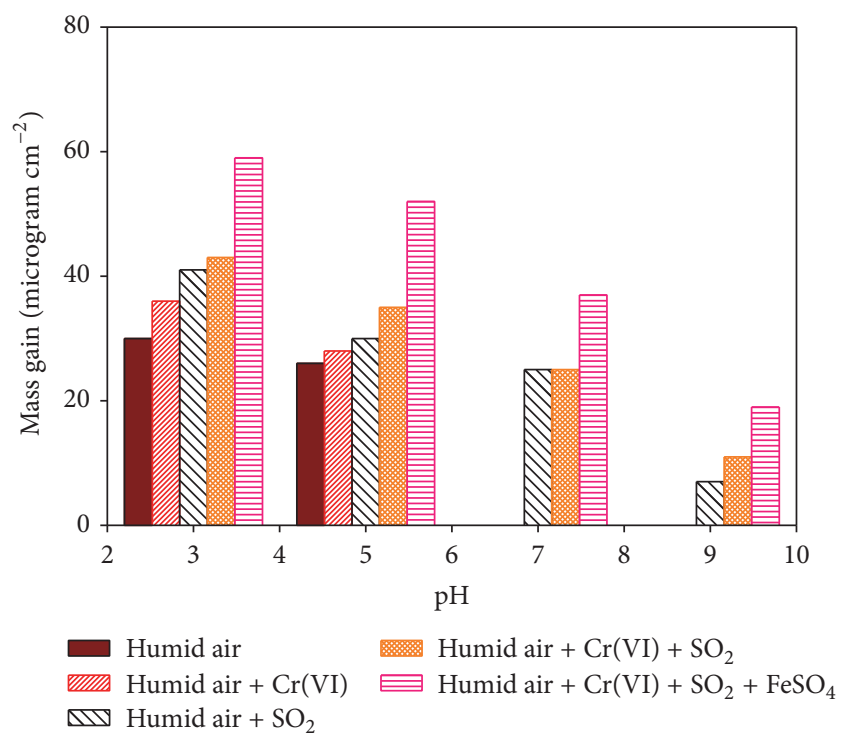

FIGURE 4: Total mass gain $\left(\mu \mathrm{g} \mathrm{cm}^{-2}\right)$ and corresponding conditions as a function of $\mathrm{pH}$ after 60 days of exposure.

[34] due to the formation of corrosion products was gravimetrically determined to compare corrosion rates. The level of total chromium was determined by FAAS and speciation into $\mathrm{Cr}(\mathrm{III})$ and $\mathrm{Cr}(\mathrm{VI})$ was carried out by first determining the hexavalent Cr through UV-Vis method and then calculating $\mathrm{Cr}$ (III) from the difference. The increment of $\mathrm{Cr}$ (III) was used as indicator of the reduction of $\mathrm{Cr}(\mathrm{VI})$ to $\mathrm{Cr}(\mathrm{III})$. Five groups of new corrugated iron samples exposed to the

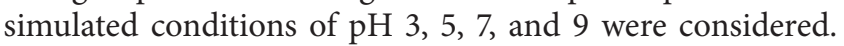
Group 1 samples consisted of samples just immersed in aqueous solutions of different $\mathrm{pH}$, dried at ambient, and exposed to humid air. The second group consisted of samples immersed in aqueous solutions of $\mathrm{Cr}(\mathrm{VI})$ under $\mathrm{pH}$ of 3 , 5,7 , and 9 and exposed to humid air. The third and fourth groups consisted of samples exposed to synthetic corrosive air containing $\mathrm{SO}_{2}$ in absence and presence of $\mathrm{Cr}(\mathrm{VI})$, respectively. All other conditions remained the same as that of group 2. Group 5 consisted of samples exposed to synthetic corrosive air containing $\mathrm{SO}_{2}$ in the presence of $\mathrm{Cr}(\mathrm{VI})$ and $\mathrm{FeSO}_{4}$. The sample was immersed in equimolar solution of $\mathrm{Cr}(\mathrm{VI})$ and $\mathrm{FeSO}_{4}$ and dried at ambient prior to exposure to the corrosive air containing $\mathrm{SO}_{2}$. The solution was prepared by dissolving predetermined amounts of $\mathrm{FeSO}_{4}$ dissolved in a $50 \mathrm{~mL}$ solution of $0.1 \mathrm{M} \mathrm{K}_{2} \mathrm{Cr}_{2} \mathrm{O}_{7}$ to form the same molar ratio. The results of laboratory exposure studies are shown in Figure 4. All the samples had the exposure times of up to 60 days.

3.4.1. Visual Observation. Visual monitoring of corrosion rate was performed based on the formation of thin layer of light brown to dark red brown rust on the surface of the exposed materials. The rate was recorded in terms of days required to observe the rust formation under different conditions. The visual observation was recorded every 12 hours starting from the first day of the exposure. After one week, visual observation showed that corrosion took place over some of the specimens that are exposed to corrosive air or acidic $\mathrm{pH}$ and the colour of the corrosion products was noted. A summary of the number of days required for the formation of the rust during the visual observation is presented in Table 1.

3.4.2. Mass Gain due to Deposition of Corrosion Products. After the immersion experiment, all samples were dried at $55-60^{\circ} \mathrm{C}$ and weighed before exposure to the corrosive air. The masses of the samples were then determined after 60 days of exposure followed by drying at $55-60^{\circ} \mathrm{C}$ for 5 minutes. The results of the laboratory exposure studies (total mass gain $\left(\mu \mathrm{g} \mathrm{cm}^{-2}\right)$ and corresponding conditions as a function of $\mathrm{pH}$ ) are shown in Figure 4. The corrosivity which also paralleled the level of $\mathrm{Cr}$ deposits was found to decrease in the order $\mathrm{Fe}^{+2}+\mathrm{Fe}^{0}+\mathrm{SO}_{2}+\mathrm{Cr}(\mathrm{VI})+$ humid air, $\mathrm{Fe}^{0}+\mathrm{SO}_{2}$ $+\mathrm{Cr}(\mathrm{VI})+$ humid air, $\mathrm{Fe}^{0}+\mathrm{SO}_{2}+$ humid air, $\mathrm{Fe}^{0}+\mathrm{Cr}(\mathrm{VI})$ + humid air, and $\mathrm{Fe}^{0}+$ humid air. This was explained by a synergistic effect of $\mathrm{SO}_{2}$ and $\mathrm{Cr}(\mathrm{VI})$ as polluting species. Further enhancement of the corrosion rate in the presence of ferrous ion is consistent with the fact that $\mathrm{Fe}^{+2}$ can undergo a thermodynamic (galvanic) coupling to the redox transformation of $\mathrm{Cr}(\mathrm{VI})$ to $\mathrm{Cr}$ (III) [35]:

$$
\begin{gathered}
3 \mathrm{Fe}^{2+} \longrightarrow 3 \mathrm{Fe}^{3+}+3 \mathrm{e}^{-} \\
\frac{\mathrm{Cr}_{2} \mathrm{O}_{7}^{2-}+14 \mathrm{H}^{+}+6 \mathrm{e}^{-} \longrightarrow 2 \mathrm{Cr}^{3+} 7 \mathrm{H}_{2} \mathrm{O}}{\mathrm{Cr}_{2} \mathrm{O}_{7}^{2-}+14 \mathrm{H}^{+}+6 \mathrm{Fe}^{2+} \longrightarrow 2 \mathrm{Cr}^{3+}+6 \mathrm{Fe}^{3+}+7 \mathrm{H}_{2} \mathrm{O}}
\end{gathered}
$$

For instance, ferrous ion has been used to remove $\mathrm{Cr}(\mathrm{VI})$ through reduction to $\mathrm{Cr}(\mathrm{III})$ followed by precipitation [6]. Several other reports also showed the use of zerovalent iron to precipitate $\mathrm{Cr}(\mathrm{III})$ by reducing the toxic $\mathrm{Cr}(\mathrm{VI})[4,7]$.

We also carried out analysis of the levels of $\mathrm{Cr}$ (III) on the samples before and after 60 days of exposure to the corrosive air using FAAS as presented in Table 2. A gradual increment in the levels of $\mathrm{Cr}$ (III) has been detected on the samples exposed to $\mathrm{Cr}(\mathrm{VI})$ under corrosive conditions. The results are consistent with the proposed coupled transformation of $\mathrm{Cr}(\mathrm{VI})$ to $\mathrm{Cr}(\mathrm{III})$. This is further verified by the hardly any change recorded with samples exposing the corrosive air in absence of $\mathrm{Cr}(\mathrm{VI})$. The data presented in Figure 4 and Tables 1 and 2 reinforce the importance of $\mathrm{pH}$ as a key factor in accelerated corrosion of the roofing iron materials involving polluting species.

\subsubsection{Impact of Local Surface Stress Cracking on Corrosion} Rate. Stress cracks and physical scratches can play a significant role in the corrosion behavior of materials [36]. When the outer protective layer of a surface is cracked or scratched, the inner layer of the material is exposed to the atmosphere. Such cracks or scratches can occur during manufacturing, transportation, or service not only by chemical means but also by friction with local materials including particulate matters, trees, and its falling parts. The latter is particularly important as it is very common to observe big shade trees near buildings and houses in Ethiopia. Thus, we considered exposure of new but scratched iron materials to corrosive 
TABLE 1: Number of days required for the formation of corrosion products (rust) under different laboratory exposure conditions.

\begin{tabular}{|c|c|c|c|c|c|}
\hline \multirow[t]{2}{*}{ Experiment group } & \multirow[t]{2}{*}{ Exposure conditions } & \multicolumn{4}{|c|}{$\begin{array}{c}\text { Number of days to rust } \\
\mathrm{pH}\end{array}$} \\
\hline & & 3 & 5 & 7 & 9 \\
\hline 1 & Humid air & 15 & 19 & $\mathrm{NO}$ & $\mathrm{NO}$ \\
\hline 2 & Humid air + Cr(VI) & 11 & 15 & 35 & $\mathrm{NO}$ \\
\hline 3 & Humid air $+\mathrm{SO}_{2}$ & 9 & 13 & 25 & 31 \\
\hline 4 & Humid air $+\mathrm{Cr}(\mathrm{VI})+\mathrm{SO}_{2}$ & 9 & 12 & 21 & 31 \\
\hline 5 & Humid air $+\mathrm{Cr}(\mathrm{VI})+\mathrm{SO}_{2}+\mathrm{Fe}^{+2}$ & 7 & 15 & 20 & 17 \\
\hline
\end{tabular}

NO: not observed in 60 days.

TABle 2: Deposition of Cr(III) as a result of coupled Cr(VI) transformation.

\begin{tabular}{|c|c|c|c|c|c|}
\hline \multirow[t]{2}{*}{ Experiment group } & \multirow[t]{2}{*}{ Exposure conditions } & \multicolumn{4}{|c|}{$\begin{array}{c}\mathrm{Cr}(\mathrm{III})(\mathrm{ppm}) \\
\mathrm{pH}\end{array}$} \\
\hline & & 3 & 5 & 7 & 9 \\
\hline 1 & Humid air & $8.9 \pm 0.45$ & $8.5 \pm 0.045$ & $8.7 \pm 0.5$ & $8.12 \pm 0.045$ \\
\hline 2 & Humid air + Cr(VI) & $11.5 \pm 0.08$ & $11.05 \pm 0.072$ & $8.9 \pm 0.47$ & $8.5 \pm 0.2$ \\
\hline 3 & Humid air $+\mathrm{SO}_{2}$ & $8.35 \pm 0.55$ & $8.5 \pm 0.019$ & $8.7 \pm 0.20$ & $8.7 \pm 0.008$ \\
\hline 4 & Humid air $+\mathrm{Cr}(\mathrm{VI})+\mathrm{SO}_{2}$ & $19.5 \pm 0.045$ & $19.02 \pm 0.064$ & $10.02 \pm 0.035$ & $9.07 \pm 0.045$ \\
\hline 5 & Humid air $+\mathrm{Cr}(\mathrm{VI})+\mathrm{SO}_{2}+\mathrm{Fe}^{+2}$ & $21.5 \pm 0.56$ & $19.5 \pm 0.53$ & $15 \pm 1.1$ & $11 \pm 0.78$ \\
\hline
\end{tabular}

NO: not observed in 60 days.

synthetic air under simulated atmospheric conditions and compared their corrosion rates with those without any surface scratches or cracks. Similar five groups of sample materials described in the above sections were considered except, in this case, the surface which is physically scratched with stainless steel before being subjected to the laboratory exposure. The results of the laboratory exposure of scratched iron materials and control samples to synthetic corrosive air under different atmospheric conditions are shown in Figure 5. Comparing the results of Figures 5 and 4, a significant effect of surface scratches on the corrosion rate was observed with all other effects appearing as presented in Figure 4. Our results point to the importance of avoiding surface scratches during manufacturing, packaging, and transporting of corrugated iron roof materials.

\section{Conclusions}

The level of Cr deposits on the samples has been spectrophotometrically determined as indicator of atmospheric $\mathrm{Cr}$ pollution leading to accelerated corrosion of the material in tanning industry zones. The experiments showed increasing level of $\mathrm{Cr}$ deposits on samples collected from industrial areas as compared to that of the alloy composition of newly manufactured material or control samples collected from presumably nonindustrial areas. The levels increased as sampling sites get closer to the tannery and in the direction of tannery effluent stream. A speciation experiment showed a similar trend in the levels of $\mathrm{Cr}$ (III) and $\mathrm{Cr}(\mathrm{VI})$ but with low levels of the latter as compared to the former. The observed results can be attributed to atmospheric $\mathrm{Cr}$ pollution of tanning industrial areas playing an important role in accelerated

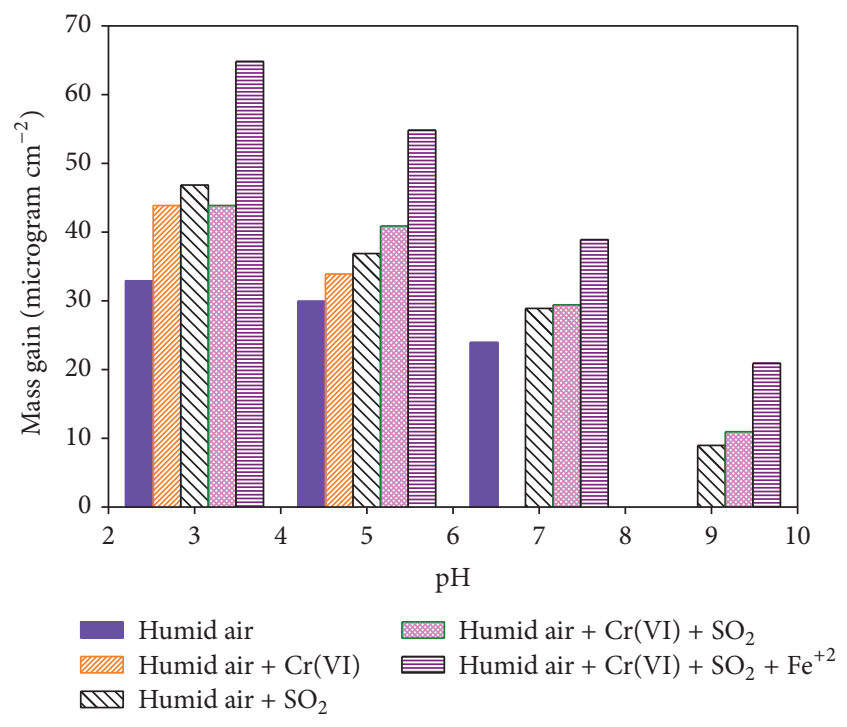

FIGURE 5: Total mass gain $\left(\mu \mathrm{g} \mathrm{cm}^{-2}\right)$ and corresponding conditions as a function of $\mathrm{pH}$ of the scratched iron roof materials after 60 days of exposure.

corrosion of the materials via a coupled redox process where $\mathrm{Cr}(\mathrm{VI})$ is reduced to a stable, immobile, and insoluble $\mathrm{Cr}$ (III) deposited on the material and accompanying corrosion of the underlying material. The findings were further verified through laboratory exposure of a newly manufactured material to a simulated synthetic corrosive air containing $\mathrm{SO}_{2}$ in the presence and absence of $\mathrm{Cr}(\mathrm{VI})$ as polluting species. A relatively faster corrosion rate was recorded in the presence of 
$\mathrm{Cr}(\mathrm{VI})$. Interestingly, a further enhancement in the corrosion rate was recorded in the presence of $\mathrm{Fe}^{+2}$ pointing to a synergistic role that $\mathrm{Fe}^{+2}$ can play as product of initial corrosion. This study also showed increased corrosion rate when the material is scratched or stress cracked. In conclusion, our results showed possible atmospheric Cr pollution of tanning industrial areas that can play important role in accelerated corrosion of corrugated iron roofs in the areas. The results also suggested the importance of avoiding surface scratches or stress cracks during corrugation, packaging, transporting, and construction or nailing.

\section{Conflicts of Interest}

The authors declare that there are no conflicts of interest regarding the publication of this paper.

\section{Acknowledgments}

The authors are very grateful to Hawassa University (HU) for providing laboratory facility for the conduct of the experiments. Dereje Homa is also grateful to the Office of Research and Technology Transfer of HU for partial financial support during the study.

\section{References}

[1] E. A. Tice, "Effects of air pollution on the atmospheric corrosion behavior of some metals and alloys," Journal of the Air Pollution Control Association, vol. 12, no. 12, pp. 553-559, 1962.

[2] S. A. Amadi and C. P. Ukpaka, "The influence of environmental acidification on the atmospheric corrosion of corrugated iron roof (zinc)," International Journal of Applied Chemical Sciences Research, vol. 1, pp. 169-181, 2013.

[3] A. Cox and S. B. Lyon, "An electrochemical study of the atmospheric corrosion of mild steel-III. The effect of sulphur dioxide," Corrosion Science, vol. 36, no. 7, pp. 1193-1199, 1994.

[4] R. M. Powell, R. W. Puls, S. K. Hightower, and D. A. Sabatini, "Coupled iron corrosion and chromate reduction: mechanisms for subsurface remediation," Environmental Science and Technology, vol. 29, no. 8, pp. 1913-1922, 1995.

[5] I. B. Singh, G. Venkatachari, D. R. Singh, M. Singh, and A. H. Yegneswaran, "Effect of $\mathrm{Cr}(\mathrm{VI})-\mathrm{Fe}(\mathrm{II})$ interaction on the corrosion resistances of iron at different $\mathrm{pH}$ in dichromate solutions," Indian Journal of Chemical Technology, vol. 12, no. 6, pp. 635-640, 2005.

[6] M. Gheju and R. Pode, "Removal of hexavalent chromium from wastewater by use of scrap iron," World Academy of Science, Engineering and Technology, vol. 42, pp. 982-987, 2010.

[7] L. E. Eary and D. Rai, "Chromate removal from aqueous wastes by reduction with ferrous ion," Environmental Science and Technology, vol. 22, no. 8, pp. 972-977, 1988.

[8] J. O. Nriagu, "Production and uses of chromium," in Chromium in Natural and Human Environments, J. O. Nriagu and E. Nieboer, Eds., pp. 81-104, Wiley Interscience, New York, NY, USA, 1988.

[9] A. D. Apte, S. Verma, V. Tare, and P. Bose, "Oxidation of Cr(III) in tannery sludge to $\mathrm{Cr}(\mathrm{VI})$ : field observations and theoretical assessment," Journal of Hazardous Materials, vol. 121, no. 1-3, pp. 215-222, 2005.
[10] Z. Stepniewska, A. Wolińska, and W. Pióro, "Chromium migration in the vicinity of a tannery waste lagoon," Polish Journal of Soil Science, vol. 40, no. 2, pp. 139-145, 2007.

[11] M. Mwinyihija, A. Meharg, J. Dawson, N. J. C. Strachan, and K. Killham, "An ecotoxicological approach to assessing the impact of tanning industry effluent on river health," Archives of Environmental Contamination and Toxicology, vol. 50, no. 3, pp. 316-324, 2006.

[12] D. Homa, E. Haile, and A. P. Washe, "Determination of spatial chromium contamination of the environment around industrial zones," International Journal of Analytical Chemistry, vol. 2016, Article ID 7214932, 7 pages, 2016.

[13] A. Wolińska, Z. Stępniewska, and R. Włosek, “The influence of old leather tannery district on chromium contamination of soils, water and plants," Natural Science, vol. 5, no. 2, pp. 253258, 2013.

[14] D. I. Khasim, N. V. N. Kumar, and R. C. Hussain, "Environmental contamination of chromium in agricultural and animal products near a chromate industry," Bulletin of Environmental Contamination and Toxicology, vol. 43, no. 5, pp. 742-746, 1989.

[15] D. C. Schroeder and G. F. Lee, "Potential transformations of chromium in natural waters," Water, Air, and Soil Pollution, vol. 4, no. 3-4, pp. 355-365, 1975.

[16] R. J. Bartlett and B. R. James, "Behavior of chromium in soils. III. Oxidation," Journal of Environmental Quality, vol. 8, no. 1, pp. 31-35, 1979.

[17] B. R. James and R. J. Bartlett, "Behavior of chromium in soils. VI. Interactions between oxidation-reduction and organic complexation," Journal of Environmental Quality, vol. 12, no. 2, pp. 173-176, 1983.

[18] B. R. James, "The complex chemistry of chromium compounds presents unique measurement and regulatory challenges," Environmental Science \& Technology, vol. 30, no. 6, pp. 248A-251A, 1996.

[19] S. L. Friess, "Carcinogenic risk assessment criteria associated with inhalation of airborne particulates containing chromium(VI/III)," Science of the Total Environment, vol. 86, no. 1-2, pp. 109-112, 1989.

[20] C. H. Seigneur and E. Constantinou, "Chemical kinetic mechanism for atmospheric chromium," Environmental Science \& Technology, vol. 29, no. 1, pp. 222-231, 1995.

[21] J. Kotaś and Z. Stasicka, "Chromium occurrence in the environment and methods of its speciation," Environmental Pollution, vol. 107, no. 3, pp. 263-283, 2000.

[22] P. K. F. Chin, "Fate and transport of chromium through soil in migration and fate pollutants in soils and subsoils," Institute of Water Research, vol. 96, pp. 61-626, 1994.

[23] P. H. Masscheleyn, J. H. Pardue, R. D. De Laune, and W. H. Patrick Jr., "Chromium redox chemistry in a lower Mississippi Valley bottomland hardwood wetland," Environmental Science \& Technology, vol. 26, no. 6, pp. 1217-1226, 1992.

[24] R. M. Powell, R. W. Puls, S. K. Hightower, and D. A. Sabatini, "Coupled iron corrosion and chromate reduction: mechanisms for subsurface remediation," Environmental Science \& Technology, vol. 29, no. 8, pp. 1913-1922, 1995.

[25] H. Ebrahimzadeh, A. A. Asgharinezhad, N. Tavassoli, O. Sadeghi, M. M. Amini, and F. Kamarei, "Separation and spectrophotometric determination of very low levels of $\mathrm{Cr}(\mathrm{VI})$ in water samples by novel pyridine-functionalized mesoporous silica," International Journal of Environmental Analytical Chemistry, vol. 92, no. 4, pp. 509-521, 2012. 
[26] M. E. Mahmoud, A. A. Yakout, S. B. Ahmed, and M. M. Osman, "Speciation, selective extraction and preconcentration of chromium ions via alumina-functionalized-isatinthiosemicarbazone," Journal of Hazardous Materials, vol. 158, no. 2-3, pp. 541-548, 2008.

[27] M. Noroozifar and M. Khorasani-Motlagh, "Specific extraction of chromium as tetrabutylammonium-chromate and spectrophotometric determination by diphenylcarbazide: speciation of chromium in effluent streams," Analytical Sciences, vol. 19, no. 5, pp. 705-708, 2003.

[28] J. Itoh, T. Sasaki, M. Seo, and T. Ishikawa, "In situ simultaneous measurement with IR-RAS and QCM for investigation of corrosion of copper in a gaseous environment," Corrosion Science, vol. 39, no. 1, pp. 193-197, 1997.

[29] T. Aastrup, M. Wadsak, M. Schreiner, and C. Leygraf, "Experimental in situ studies of copper exposed to humidified air," Corrosion Science, vol. 42, no. 6, pp. 957-967, 2000.

[30] T. Aastrup, M. Wadsak, C. Leygraf, and M. Schreiner, "In situ studies of the initial atmospheric corrosion of copper influence of humidity, sulfur dioxide, ozone, and nitrogen dioxide," Journal of the Electrochemical Society, vol. 147, no. 7, pp. 25432551, 2000.

[31] M. Wadsak, M. Schreiner, T. Aastrup, and C. Leygraf, "Combined in-situ investigations of atmospheric corrosion of copper with SFM and IRAS coupled with QCM," Surface Science, vol. 454, no. 1, pp. 246-250, 2000.

[32] T. Aastrup and C. Leygraf, "Simultaneous infrared reflection absorption spectroscopy and quartz crystal microbalance measurements for in situ studies of the metal/atmosphere interface," Journal of the Electrochemical Society, vol. 144, no. 9, pp. 29862990, 1997.

[33] A. Jänes and E. Lust, "Electrochemical characteristics of nanoporous carbide-derived carbon materials in various nonaqueous electrolyte solutions," Journal of the Electrochemical Society, vol. 153, no. 1, pp. 113-116, 2006.

[34] S. Lee and R. W. Staehle, "Adsorption of water on copper, nickel, and iron," Corrosion, vol. 53, no. 1, pp. 33-42, 1997.

[35] B. M. Voelker and D. L. Sedlak, "Iron reduction by photoproduced superoxide in seawater," Marine Chemistry, vol. 50, no. 1-4, pp. 93-102, 1995.

[36] F. Meng, J. Wang, E.-H. Han, and W. Ke, "Effects of scratching on corrosion and stress corrosion cracking of Alloy 690TT at 58 ${ }^{\circ} \mathrm{C}$ and $330^{\circ}$ C," Corrosion Science, vol. 51, no. 11, pp. 2761-2769, 2009. 

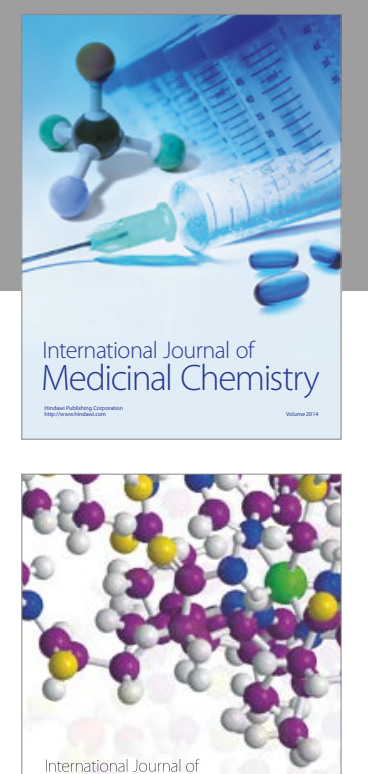

Carbohydrate Chemistry

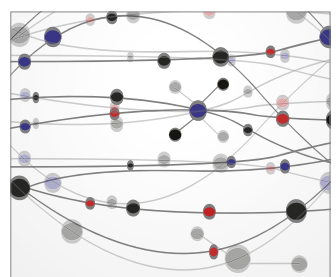

The Scientific World Journal
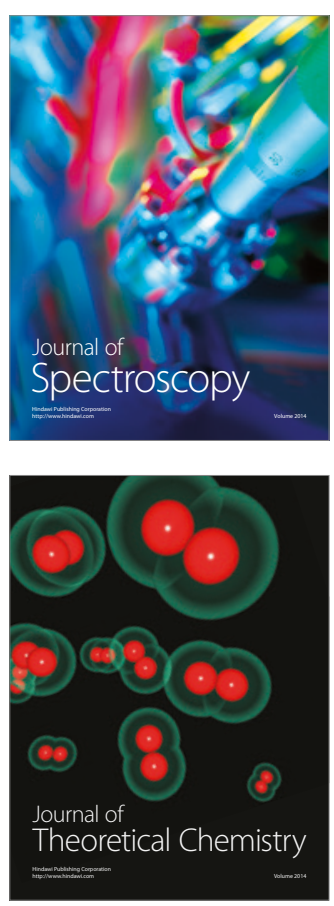
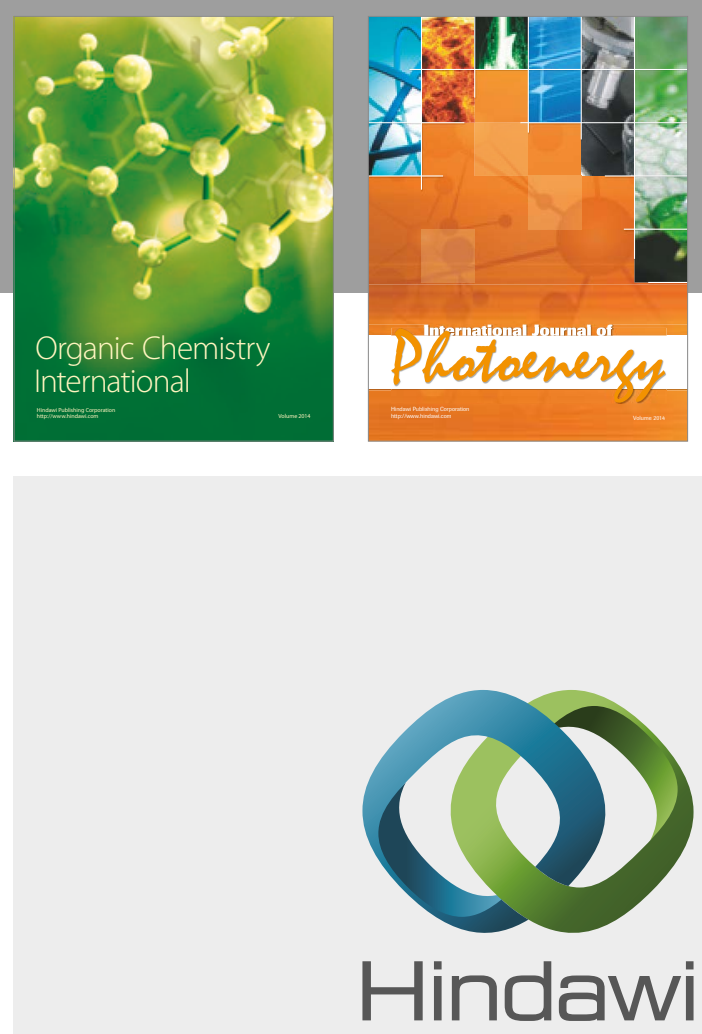

Submit your manuscripts at

https://www.hindawi.com

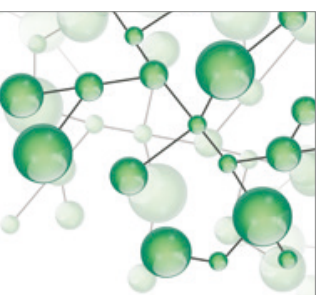

International Journal of

Inorganic Chemistry

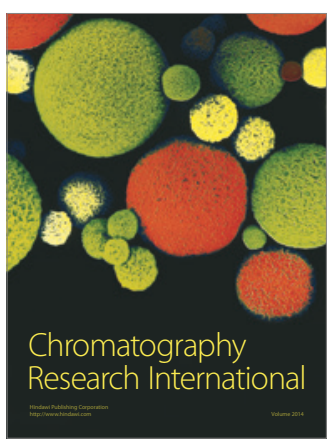

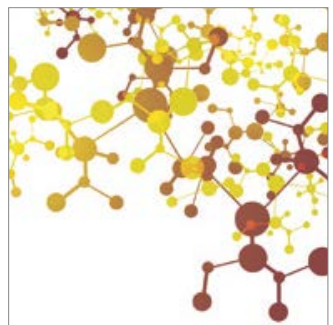

Applied Chemistry
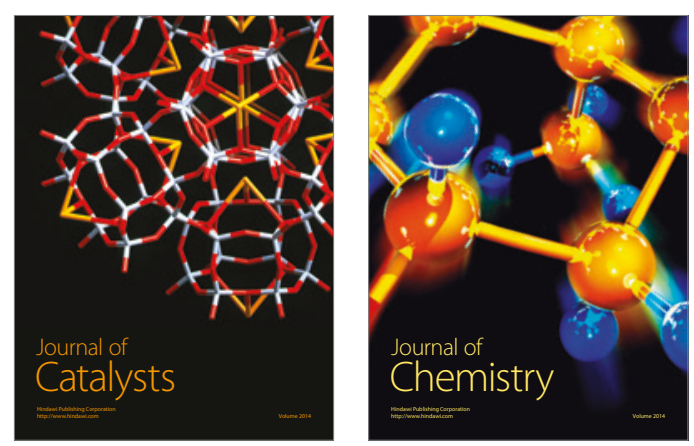
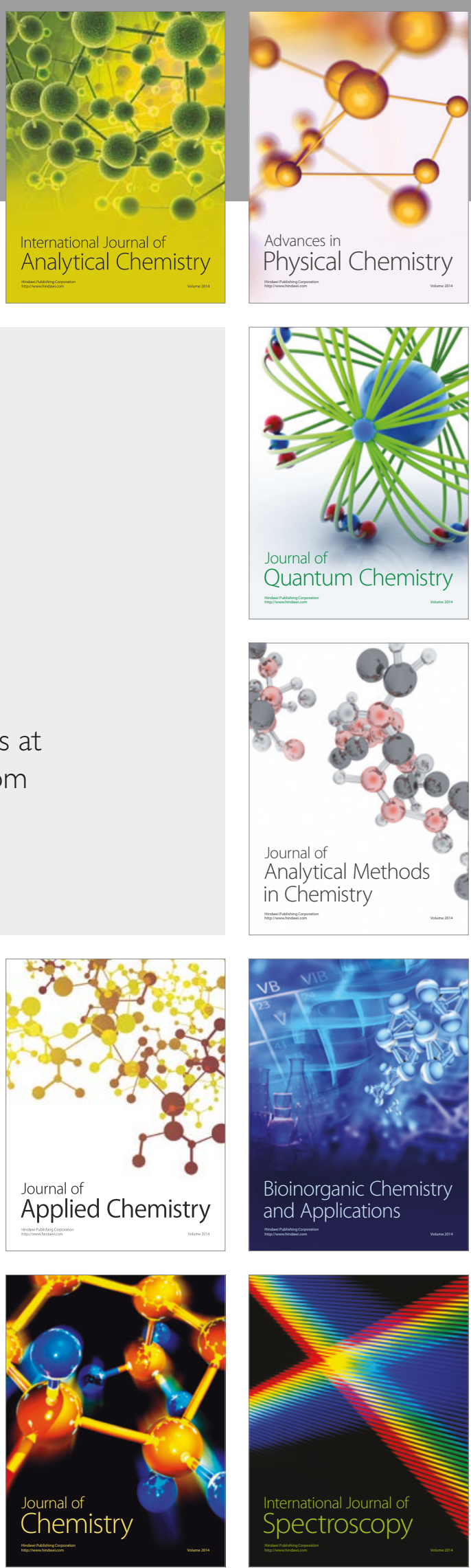